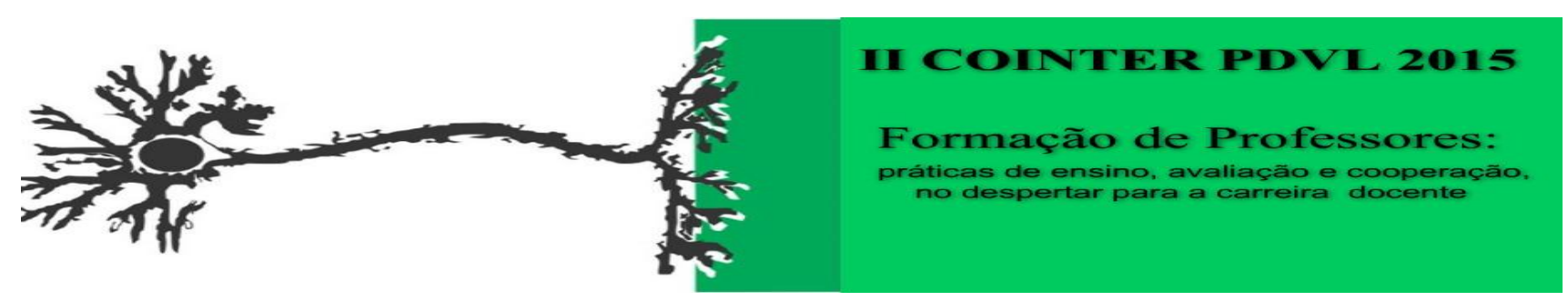

\title{
USO DE PAINEL GEOGRÁFICO: UMA FERRAMENTA SOCIALIZADORA NO ENSINO E APRENDIZAGEM COM OS ALUNOS DA EDUCAÇÃO DE JOVENS E ADULTOS
}

(EJA).

\author{
Apresentação: Relato de Experiência \\ Nilma Cavalcanti Andrade ${ }^{1}$; Raílson Pereira Figueiredo ${ }^{2}$; Paloma Batista Maia ${ }^{3}$; Levi \\ Rodrigues Miranda ${ }^{4}$.
}

\section{Introdução}

O Programa Institucional de Bolsa de Iniciação à Docência (PIBID) chega para estimular o licenciando a conhecer a realidade escolar e o exercício à docência. Atuando na Escola Estadual Walter Duarte Pereira em Natal/RN, entendemos que ser um professor vai além das técnicas acadêmicas e nos remete a construção de novos momentos adequando os conteúdos de forma mais atrativa, onde são inseridas metodologias educacionais de práticas como o painel geográfico desenvolvido nas turmas de Ensino de Jovens e Adultos (EJA) como uma necessidade prática que permiti analisar e refletir o espaço geográfico e apostar no potencial explicativo da realidade e o reconhecimento educacional da geografia (CARLOS, 2009).

Num contexto social e na condição básica de conhecimentos prévios dessa modalidade de ensino que aumentaria sua capacidade de decodificação da linguagem ao ler e escrever sobre as figuras. Refletir criticamente sobre seu processo de aprendizagem e seu profundo significado da linguagem.

\section{Relato de Experiência}

A produção dos painéis teve a participação das turmas de EJA, onde foi elaborado slides para escolha das figuras a serem desenhadas no painel, feito a escolhas por parte da maioria dos alunos, as figuras usadas foram ampliadas com a ajuda do projetor. As imagens foram desenhadas sobre 7 metros de TNT branco, posteriormente foi realizada a pintura com giz de cera, distribuindo

\footnotetext{
${ }^{1}$ Licencianda em Geografia, IFRN, nilma,cavalcanti@hotmail.com

${ }^{2}$ Licenciando em Geografia, IFRN, railson.figueiredo@yahoo.com.br

${ }^{3}$ Licencianda em Geografia, IFRN, Iola_ursinha@hotmail.com

${ }^{4}$ Mestre em Arquitetura e Urbanismo/ Doutorando em Ciências da Educação - Especialidade Desenvolvimento, Universidade do Minho - UMINHO, Braga / Portugual, levi.miranda@ifrn.edu.br
} 
os desenhos pelas turmas participantes e a finalização com a exposição do painel na sala.

Finalizando a produção do painel, foi proposta uma atividade de fixação, em que os alunos desenvolveram um texto sobre o que entenderam das imagens e as relações que elas podiam estabelecer entre o cotidiano vivido e as realidades que as figuras associavam com a realidade vivida no entorno da comunidade escolar, do bairro e do municipio como mostra a figura 1.

Figura 1: produção do painel geográfico. Fonte: Própria

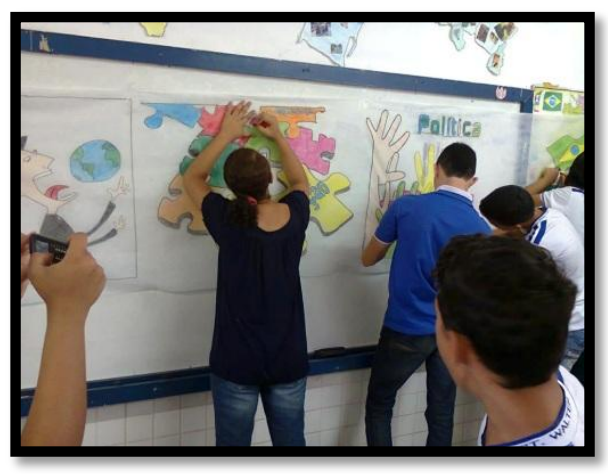

\section{Considerações}

Esta foi uma das atividades do PIBID mais populares na Escola Estadual Walter Duarte Pereira, pois todos os alunos queriam participar. Utilizar elementos (desenho, pintura) para a promoção da interpretação de imagens, fazendo uma ponte com os temas trabalhados durante as aulas de geografia. Atividades como essas são de grande auxilio no desenvolvimento dos alunos como também na compreensão de conceitos para o entendimento. Trabalhando em conjunto, no sentido de formação de grupo para desenvolver competências que permitam realmente aprender com o outro e construir de formar participativa. Além do mais essa atividade foi um sucesso entre os PIBIDS de geografia do IFRN Campus Natal Central, e alcançou outros públicos, com fácil aceitação e execução, já que a técnica é simples de fácil execução.

\section{Referências}

CARLOS, Ana Fani Alessandri et al. (org.). A geografia na sala de aula. São Paulo: contexto, 2009. ed. 8, 144 p. 